\title{
TALAJOK SZEREPE A KLÍMAVÁLTOZÁSBAN
}

\author{
Bidló András és Horváth Adrienn \\ Soproni Egyetem, Környezet- és Földtudományi Intézet
}

\begin{abstract}
Kivonat
A klímaváltozás jelentős hatással lesz erdőállományainkra. Ez a hatás egyrészt közvetlenül érvényesül, hiszen a klíma az egyik legfontosabb termőhelyi tényező, másrészt más termőhelyi tényezők, mint a hidrológiai- és a talajviszonyok megváltoztatásán keresztül. Utóbbiakban bekövetkező változások egy része viszonylag gyors, egyes esetekben akár egy vegetációs időszak alatt is jelentős változás történhet, más tényezök, hosszabb időszak, akár több száz év alatt jelentkezhetnek. Munkánkban felmértük, hogy a klimatikus változások milyen hatással lehetnek a talajokra. A klímaváltozás hatása elsősorban a talajképző folyamatok megváltozásán keresztül jelentkezhet, így ezek értékelésével mutattuk be a várható változásokat. A talajképző folyamatok megváltozása mellett, értékeltük az erdőállományok anyagforgalmában bekövetkező lehetséges változásokat is.

A termőhelyi tényezök megváltozása és az új - sztyep - klímakategória megjelenése új termőhely típus változatok megjelenését is magával vonzza. Munkánk második részében ismertetjük, hogy milyen termöhelytípus változatok megjelenésével számolhatunk, illetve ezekre milyen alapon adhatunk fafaj-javaslatot. A bevezetés alatt álló Döntés Támogató Rendszernek (DTR) megkönnyíti a jövöben alkalmazható fafajok kiválasztását.
\end{abstract}

Kulcsszavak: éghajlatváltozás, termőhelyváltozás, fafajválasztás, talaj.

\section{ROLE OF SOILS IN CLIMATE CHANGE}

\begin{abstract}
Climate change will have a significant impact on forest cover of Hungary. Climate is one of the most important site factors therefore, it has a direct influence on forests. On the other hand, the climate has an indirect impact on the change of other site factors, such as hydrological and soil conditions. Some changes occur relatively fast, thus a significant change may happen during a single vegetation period. Some other factors need longer periods or hundred of years for transformation. During our research, we estimated the impact of climate change on soils. Soils not only create the foundations of human, animal and plant life but also have a very important role in regulation and production. Significant changes in soil-forming processes may emerge as a result of climate change. Along with the change in soil-forming processes, we also evaluated possible changes in the nutrient cycle of forest stands.

The appearance of changing site factors and the emergence of a new climate category - steppe - will determine new site type variants. To summarize, we described what kind of site type variants can be expected in the future and what kind of criteria are needed for a tree species proposal. It provides a good basis for a Decision Supporting System (DTR) which will facilitate the selection of tree species in the future.
\end{abstract}

Keywords: climate change, site change, tree species selection, soil. 


\section{BEVEZETÉS}

Az egyes fafajok, illetve erdőállományok előfordulását, növekedését és egészségi állapotát alapvetően meghatározzák a termöhelyi körülmények. A hazai erdészeti termöhelyosztályozás alapvetően a klíma, a hidrológia és talaj értékelésével foglalkozik, ugyanakkor figyelembe veszi a tengerszint feletti magasság, a kitettség, a lejtszög és az alapkőzet szerepét is (Babos et al. 1966).

A termőhelyi tényezőket sokáig állandónak tekintették, azonban az elmúlt évtizedekben megfigyelhettük az egyes tényezők hosszabb, vagy rövidebb idő alatt bekövetkező változását. Az első publikációk elsősorban a hidrológiai viszonyok, azaz a talajvízszint változását jelezték (Magyar 1993, Szodfridt 1994, Jankó 2013), de az elmúlt évtizedben - részben a VKSZ Agrárklíma 2 projekt eredményei alapján - a klíma változását is vizsgáljuk.

A klimatikus tényezök és a talajok között igen szoros kölcsönhatás van, egyrészt a légköri hőmérséklet korrelál a talajhőmérséklettel, másrészt a talaj igen nagy mennyiségü vizet képes tárolni, amely párolgásával jelentősen befolyásolja a helyi klimatikus viszonyokat. Ugyanakkor a talajok kialakulását és tulajdonságait alapvetően meghatározzák a klimatikus körülmények, részben közvetlenül ( $p l$. a csapadék beszivárgásával), részben közvetve (a vegetáción keresztül) (Schachtschabel et al. 1982, Stefanovits et al. 1999). Ha megváltoznak a klimatikus körülmények, akkor rövidebb-hosszabb idő után a talajok átalakulásával számolhatunk.

A jelenlegi ismereteink szerint (Bartholy et al. 2017) az utóbbi három évtizedben, éves átlagban $1,2-1,8{ }^{\circ} \mathrm{C}$, nyáron $2{ }^{\circ} \mathrm{C}$ hőmérséklet növekedéssel kell számolnunk. Ezzel egyidejűleg nőtt a meleg szélsőségek (aszályok) száma és aránya. Az éves csapadék mennyisége csak kis mértékben változott, de nőtt a száraz időszakok hossza, illetve a lehulló csapadék intenzitása. A különböző elöre becslések - bár eltérő mértékben - de ezen tendenciák fennmaradását, illetve részben erősödését vetítik elöre. A klímaváltozás hatására a talajokban közvetlenül két változás következik be, egyrészt növekszik a talajok hőmérséklete, másrészt csökkeni fog a talajok nedvességtartalma. Németországi adatok azt mutatják (Koch 2010), hogy 1951 óta a talajok hömérséklete $100 \mathrm{~cm}$ mélységben átlagosan $+0,037{ }^{\circ} \mathrm{C}$-al növekedett évenként.

A csapadék mennyisége és eloszlása, valamint a hőmérséklet változása elsősorban a talajok víz- és tápanyagháztartására hat. Megváltozik a talajok víztartalma, a párolgás és a talajvíz képződésének mértéke. Ugyanez érvényes a talajok anyagforgalmára és az egyes anyagok (pl. nitrát) kimosódására. Ezzel egyidejüleg megváltozhat a talajtömörödés és az erózió mértéke is.

Vizsgálataink során elsősorban a többletvízhatástól független termőhelyeken áló erdőállományokban - ilyen a hazai erdőállományok $80 \%$-a (AESZ 2002) - bekövetkező változásokat kívántuk megbecsülni, mivel ma még nem tudjuk, hogy a jövőben a talajvíz szintje miként változik meg. Irodalmi adatok és saját tapasztalataink alapján áttekintettük, hogy a klimatikus változások miként befolyásolhatják a talajképző folyamatok megjelenését. Az ér- 
tékelést nagyban megkönnyítette, hogy a magyarországi talajosztályozási rendszer genetikai és tájöldrajzi elveken nyugszik (Stefanovits et al. 1999), ahol az egyes osztályok elkülönítése a talajképző folyamatok megjelenése és ezek hatása alapján történik. Ez lehetővé teszi, hogy az egyes talajtípusok közötti különbség megjelenését és a klimatikus viszonyok kapcsolatát jobban ki tudjuk mutatni. Munkánk során a különböző talajképző folyamatokat értékeltük.

Munkánk második részében foglalkozunk azzal, hogy milyen hatással lesz az erdőállományok anyagforgalmára a klímaváltozás, illetve miként egészíthetjük ki a jelenlegi termőhelytípus változatokat.

\section{EREDMÉNYEK}

\section{Változás a talajképződési folyamatokban}

Az egyes talajképződési folyamatok időbeni lefolyása igen eltérő lehet. A talajokban lejátszódó kémiai reakciók (pl. komplexképződés, ioncsere, szorpció) akár néhány tized másodperc alatt megtörténhetnek. Más folyamatok (pl. ionok hidrolízise, gócképződés) inkább percek, vagy napok alatt zajlanak le, és végül vannak olyan folyamatok, mint pl. az ásványok képződése amelyek több év, vagy akár ezer év alatt zajlanak le (Stefanovits et al. 1999.) Ennek megfelelően a klímaváltozás hatására a talajokban bekövetkező változások, illetve átalakulások is igen hosszú időtávlatúak lehetnek, de vannak olyan hatások (pl. erózió), amelyek igen rövid idő alatt megváltoztathatják a talaj tulajdonságait. A következőkben a korábban ismertetett módon megpróbáljuk meghatározni, hogy milyen változások következhetnek be a talajképződésében a klímaváltozás hatására és ennek milyen hatása lehet a talajok tulajdonságára. Az alábbiakban nem tárgyaljuk az összes talajképző folyamatot, hanem csak azokat, amelyekre jelentősebben hathat a klímaváltozás.

\section{Mállás}

A talajképződés első lépcsője a mállás, ami magába foglalja a kőzetek aprózódását (fizikai mállás), az ásványok átalakulását (kémiai mállás), illetve az ezekhez kapcsolodó biológiai folyamatokat (biológiai mállás). A mállási folyamatok nem választhatók egyértelműen külön a talajképzédés többi folyamatától, ebben a részben csak a szükebb értelemben vett mállási folyamatokat tárgyaljuk (Stefanovits et al. 1999). A közetek aprózódását elsősorban fizikai folyamatok segitik elő (1. ábra). Ezen folyamatok nagy része szoros kapcsolatban áll az időjárással. Mérsékelt égövben az egyik leghatékonyabb mállási folyamat a fagy okozta aprózódás, amelyet a víz megfagyásakor történő kitágulása okoz. Ez a hatás elsősorban olyan helyeken erős, ahol éjszakai fagy után, nappal a hömérséklet $0{ }^{\circ} \mathrm{C}$ felé emelkedik, így a fagy-olvadás folyamat gyakran ismétlödik, ilyen terület jelenleg hazánk is. A téli hőmérséklet növekedésével, ritkábbá vállhatnak a fagyok, így ez a hatás kis 
mértékben csökkenhet. Hasonló aprózódást vált ki a kőzetek felszínének felmelegedése. A direkt napsugárzás hatására a kőzetek felszíne jelentősen felmelegedhet, ami az egyes ásványok kitágulását eredményezheti. Mivel a különböző színű ásványok, illetve a kőzetek belseje és külseje eltérő mértékben melegszik fel, valamint az egyes ásványoknak eltérő a tágulási együtthatója, a kőzeten belül igen nagy feszültségek keletkezhetnek, ami elősegíti az aprózódást. Ezt a típust sivatagi aprózódásnak nevezzük, mivel elsősorban a száraz területeken fordul elő. A nyári hőmérséklet emelkedésével számolnunk kell ezen aprózódási folyamat erősődésével. Összességében kijelenthetjük, hogy bár a klímaváltozozás befolyásolni fogja a kőzetek fizikai mállásának mértékét, ez a hatás viszonylag kicsi, és a különféle hatások részben kiegyenlítik egymást.

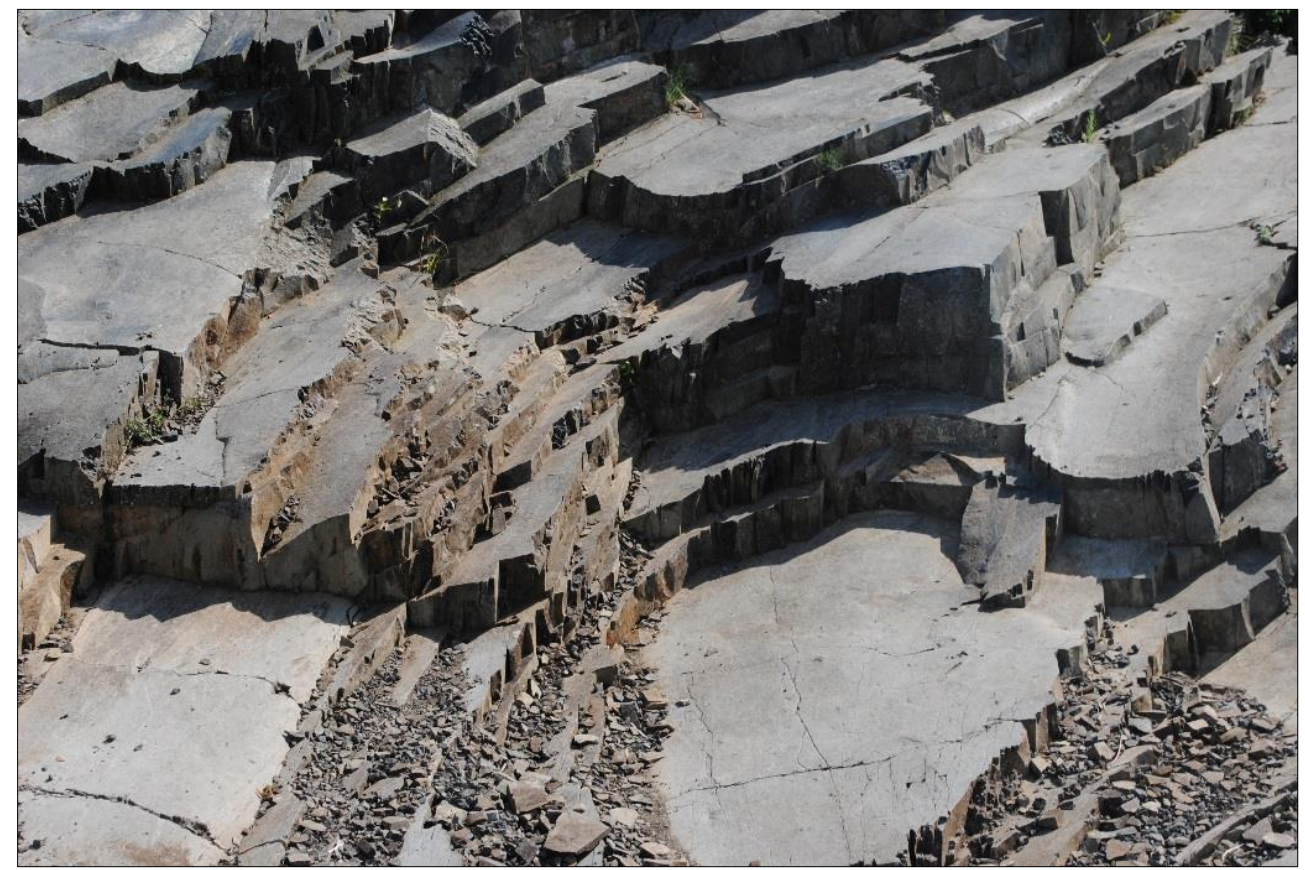

1. ábra: Bazalt aprózódása, Boszorkánykő (Salgótarján).

Figure 1: Physical weathering of basalt Boszorkánykő (Salgótarján).

A kémiai mállás elsősorban az elsődleges szilikátok (pl. földpátok) másodlagos szilikátokká (pl. agyagásványok) való átalakulását foglalja magába, ami elsősorban hidrolízíssel és hidratációval történik. Mindkét folyamat víz jelenlétében történik csak meg, így száraz talajokon nem léphet fel az átalakulás. Bár a hőmérséklet emelkedés gyorsítja a folyamatot, az víz nélkül nem történhet meg. Ennek megfelelően hazánk nedvesebb tájain, az év egy részében gyorsulhat a folyamat, a szárazabb tájakon lassulni fog a kémiai mállás. 


\section{Szerves anyag felhalmozódása}

A Föld egyik legfontosabb széntárolói a talajok. A talajok szerves anyagában mintegy 1500 milliárd tonna szén tárolódik, ami ötször annyi mint a föld feletti biomasszában és kétszer annyi, mint a légkörben tárolt szén mennyisége. A talajban tárolt szerves szén a talajélölényekböl (pl. gombák, algák, giliszták, rovarok) valamint az elhalt és átalakult állatiés növénymaradványokból áll. A talajokban található szerves anyag alapvető fontosságú a talaj termőképessége szempontjából és jelentős hatást gyakorol több talajtulajdonságra és funkcióra, amelyek közül a tápelemkörforgalmat, a talaj szürési és pufferolási képességét, a biológiai aktivitás növelését és a talaj szerkezetére gyakorolt hatást érdemes kiemelni. A talajok szerves anyagtartalmát (általános névvel humusz) a talajtípus, a klíma, a domborzat, a talajvíz előfordulása, a növényzet típusa és a gazdálkodási mód határozza meg. Jelentős befolyásoló tényező a talajra kerülő szerves anyag mennyisége és minősége valamint a talajélőlények aktivitása.

A talajra kerülő szerves anyag mennyiségét alapvetően a felszín felett keletkező biomassza mennyisége befolyásolja. A növények az általuk a légkörböl felvett széndioxid egyik felét a fotoszintézis során szerves anyaggá alakitják át, a másik felét légzéssel (pl. gyökér légzés) újból a légkörbe bocsátják ki. Hazai viszonyok között - többletvízhatástól független hidrológiai kategóriában - legtermékenyebbnek a bükkös klímában található erdőállományok tekinthetők, így itt a legnagyobb a keletkező szerves anyag mennyisége (Führer et al. 2011). Ugyanakkor a talajban tárolt szervesanyag mennyiségét elsősorban nem a rá kerülő szerves anyag mennyisége, hanem annak lebomlása határozza meg. A hazai talajfejlődési folyamatok vizsgálata azt mutatja, hogy a lebomlást elsősorban két tényező a téli hideg és a nyári szárazság akadályozza. Vizsgálataink azt mutatják, hogy azonos alapkőzeten (pl. löszön) kialakult talajok esetén a szárazabb területeken keletkező csernozjom talajok lényegesen több szerves szént tartalmaznak, mint a nedves területeken, erdők alatt képződő barna erdőtalajok. Ezen eredmények egybevágnak az egyes erdőállományokra vonatkozó adatokkal (Führer et al. 2014). Ezek alapján feltételezhetjük, hogy bár a klímaváltozás hatására csökken a biomassza produkció, a talajokban felhalmozódott szerves szén mennyisége - a lebomlási folyamatok gátlódása miatt - akár növekedhet is. A nemzetközi irodalom általában ezzel ellentétes hatást, azaz talaj szerves anyag tartalmának csökkenését jelzi elöre (Blum 2007). A 2003-as, szélsőségesen meleg év jelentősen növelte a talaj széndioxid kibocsátását (EU 2011). Kérdéses, hogy ez a növekedés a hazai szárazabb körülmények között is fellép-e, ahol a mikrobiológiai aktivitást nem elsősorban a hőmérséklet, hanem a szárazság gátolja.

Más a helyzet a többletvizes termőhelyeken. $A$ hazai láp és réti talajokon gyakran a víz telítettség miatt fellépő oxigén hiány gátolja meg a szerves anyag lebomlását, amely folyamat eredménye a talajokban képzödő tőzeg réteg. Hansági vizsgálataink is azt mutatták, hogy e réteg több ezer évig is tárolja a növények által (Bidló et al. 2018) a levegőböl felvett szenet (2. ábra). Ugyanakkor e tőzeges szint lebomlása a talajvízszint csökkenés eredményeképpen néhány évtized alatt is megtörténhet. 


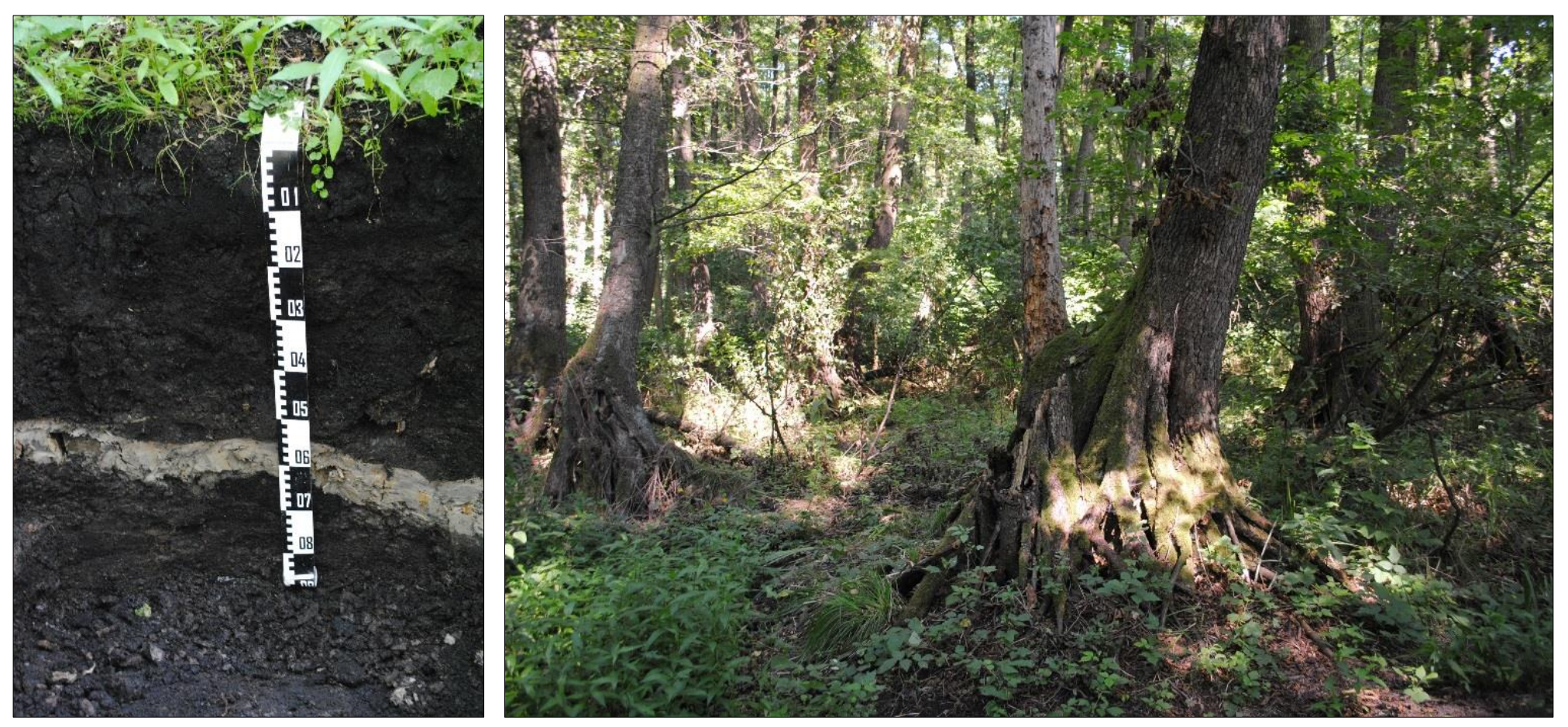

2. ábra: A hansági Csíkos-éger kotus láptalaja és a rajta található éger állomány Figure 2: Alder stand on peat soil in Hansag, Csíkos-éger 
A hansági Csíkos-égeresben végzett vizsgálataink azt mutatták, hogy a talajban a szerves szén, 4-5 ezer évvel ezelött elhalt növényekböl is származhat. A szerves szintek ugyanakkor a vízszint süllyedés után akár néhány évtizeden belül lebomolhatnak a talaj megnövekedett oxigén tartalmának köszönhetően fellépö mikrobiológiai bomlás eredményeképpen. A klímaváltozás egyik nagy kérdése, hogy a globális felmelegedés hatására olvadó fagyott talajok, illetve kiszáradó lápok milyen mennyiségben bocsájtanak ki - a szerves anyag lebomlása miatt - $\mathrm{CO}_{2}$-ot és egyéb vegyületeket. Az így kibocsátott $\mathrm{CO}_{2}$ mennyiségét az EU területén évente 100 millió tonnára becsülik (EU 2011). Mivel hazánkban a lápok lecsapolása már korábban megtörtént, ma már viszonylag kis mennyiségü $\mathrm{CO}_{2}$ kibocsátással kell számolnunk ebböl a forrásból, ugyanakkor, ha a talajvízszint csökkeni fog és új területek száradnak ki, a kibocsátás növekedhet.

Az európai talajok mintegy 75 milliárd tonna szerves szenet tartalmaznak, ami 275 milliárd tonna $\mathrm{CO}_{2}$-nek felel meg (EU 2011). Figyelembe véve, hogy az európai $\mathrm{CO}_{2}$ emmisszió évente mintegy 4 milliárd tonna, igen fontos, hogy a talajok szerves szén tartalmát megőrizzük, illetve növeljük. Vizsgálataink azt mutatták, hogy a szántóföldeken történő erdősítések, nem csak a biomasszában kötik meg a $\mathrm{CO}_{2}$-t, hanem hosszabb távon növelik a talajban tárolt szerves anyag, így szén mennyiségét is (Bidló et al. 2014). A klímaváltozáshoz való adaptáció során bekövetkező művelés váltáskor, illetve ezen belül a művelési módok megválasztásánál figyelembe kellene venni nem csak a biomasszában, hanem a talajokban megkötött szén mennyiségét (Somogyi et al. 2013). Ugyanakkor a különbő vizsgálatok azt mutatják, hogy a legtöbb országban csökken a talajokban tárolt szerves szén mennyisége (EU 2011). A talajokban tárolt szerves szén mennyiségét tovább csökkentheti a sivatagosodás és az erózió is.

\section{Kilúgzás}

A kliúgzás alatt általában a szénsavas mésszel azonosan, vagy annál könnyebben oldódó anyagoknak a talajszelvényböl, vagy annak valamely szintjéböl történő kimosódását értjük (Stefanovits et al. 1999). A kilúgzás mértékét elsősorban a talajban lefelé áramló víz mennyisége határozza meg, de erősen befolyásolja a kémhatás és a redoxi viszonyok is. $A$ talajban lefelé áramló víz mennyisége a csapadék mennyiségétől és az evapotranspiráció mértékétől függ. Erdőállományokban erősebb a kilúgzás, mert a fák gyökere mélyebb rétegekböl veszi fel a vizet, mint a lágyszárú növényeké, így több a lefelé áramló víz mennyisége, ezzel egyidejüleg a fák avartakarója savanyúbb kémhatású, ami szintén a kilúgzás erősödését vonja maga után.

A klímaváltozás eredményeképpen - feltételezve, hogy a növényzet összetétele jelentősen nem változik - azzal számolhatunk, hogy az evapotranszspiráció növekedni fog. $2{ }^{\circ} \mathrm{C}$-os hőmérséklet emelkedés átlagos becslés alapján 5-6\%-os növekedést eredményez az aktuális párolgásban, így ennyivel csökken a lefelé áramló víz mennyisége (Csáki et al. 2018), ami a kilúgzás csökkenéséhez fog vezetni. Mivel a kilúgzási folyamatok hatására 
bekövetkező $\mathrm{CaCO}_{3}$ vesztés igen hosszú - több évszázadon át tartó - folyamat, ez nem jelenti talajaink gyorsabb átalakulását. Ugyanakkor a talajok mésztartalma kevésbé fog csökkeni, ami a vízháztartás romlását hozhatja magával.

\section{Agyagosodás}

A talajképződési folyamatokban jelentős az elsődleges - föleg szilikátos ásványok átalakulása agyagásványokká (Stefanovits et al. 1999). Ennek eredményeképpen nő a talajban található agyagásványok mennyisége, ami javítja a talaj víz- és tápanyagtároló képességét. $1 \mathrm{~m}^{2}$ talaj felszín alatt, akár $50-200 \mathrm{~kg}$ agyag is keletkezhet. Az igen lassú folyamat egyik előfeltétele a kilúgzás megléte, ennek megfelelően a klímaváltozás hatására a folyamat csökkeni fog, de ez az egyes talajok tulajdonságában jelentős változást nem eredményez. Az agyagosodás változása föleg a barna erdőtalajok és kőzethatású talajok átalakulását befolyásolhatja, amely hazánk erdőterületének, közel $59 \%$-át érintheti (AESZ 2002)

\section{Agyagbemosódás és podzolosodás}

Mindkét folyamat kapcsolódik a talajok kilúgzásához és a lefelé áramló vízhez. Agyagbemosódás alatt az A-szint agyagtartalmának lefelé áramlását és a B-szintben való felhalmozódását értjük (Stefanovits et al. 1999). Ezen folyamat eredményeképpen jöttek létre hazánk legtermékenyebb erdei talajai, az agyagbemosódásos barna erdőtalajok. Viszonylag lassú folyamatról van szó, amely elsősorban hazánk csapadékosabb részein jelent csak meg, ennek megfelelően a szárazodással az agyagbemosódás mértéke csökkeni fog, de ez nem jelent jelentősebb változást a talaj tulajdonságaiban. Hasonlóan igaz a podzolosodásra is, azaz az agyagásványok szétesésére, mivel hazánkban már a jelenlegi klimatikus viszonyok sem teszik lehetővé podzol talajok létrejöttét, ilyenekkel a hüvősebb és csapadékosabb klimatikus viszonyok között találkozhatunk, ennek megfelelően a változás nem lesz jelentős.

\section{Szikesedés}

Hazánkban az elmúlt évszázadok vízrendezése és a klíma változása jelentős hatással volt talajaink szikesedésére. A szikes talajok képződésében elsősorban a száraz klímának és a felszín közeli, oldott sókat tartalmazó talajvíznek van kiemelt szerepe (Tóth et al. 2006). Ott, ahol a potenciális evapotranspiráció meghaladja a csapadék mennyiségét és van felszín közeli talajvíz, a talajban felfelé irányuló vízmozgás alakulhat ki, amely magával viszi a talajban található oldott sókat is. A szárazabb időjárás növelheti a felfelé áramló víz mennyiségét, így fokozódhat a sziksók elhalmozódása a felső szintekben. Ugyanakkor a talajvízszint süllyedése ettől eltérő eredménnyel jár, mivel a mélyebb talajvízszint már nem teszi lehetővé a felszín közeli só utánpótlást. Ennek megfelelően azokon a területeken, ahol 
csökken a talajvíz szintje, csökkenhet a szikesedés mértéke, hiszen az év egy részében (pl. télen) lefelé irányuló víz áramlás van a talajban, ami a sókat is magával viszi. Az elmúlt évtizedekben - elsősorban a vízrendezés hatása miatt - hazánkban csökkent a sziksók felhalmzódása a felsőbb talajrétegekben (Margóczi et al. 2009). Ennek megfelelöen különösen a Duna-Tisza közén - csökkent a szikesedés mértéke (Tóth et al. 2001). Ma még nem tudjuk elörebecsülni, hogy milyen hatása lesz a klímaváltozásnak a talajvíz szintjére, így ennek megfelelően nehéz elöre megmondani a szikesedés mértékének változását. A jelenlegi adatok azt mutatják, hogy vannak olyan területek, ahol nőtt a talajvíz szintje, de nagyobb kiterjedésüek azon területek, ahol csökkent. A változást elsősorban a helyi domborzati és vízrajzi adottságok határozzák meg. Összességében kijelenthetjük, hogy a szikesedés mértékének változása - ma még - nem becsülhető módon határozza meg erdőállományaink jövőjét.

\section{Erózió}

A talajok fejlődése során vannak olyan folyamatok is, amelyek hatására a talajokban igen rövid idő alatt következik be jelentős változás. Ezek általában a talajok leromlását, degradációját okozzák. A talaj degradációban kiemelt szerepet játszanak az eróziós folyamatok, amelyek között különválasztjuk a víz okozta erózót, illetve a szél okozta deflációt (Stefanovits et al. 1999). A vízerózió előfeltétele a hirtelen lehulló nagy mennyiségü csapadék, vagy a tartós csapadék. Mindkét esetben a talajba, vagy annak egyes rétegeibe nem képes már a víz beszivárogni, amely eredményeképpen lejtős területeken megindul a talajszemcsék elmozdulása. A vízeróziót több tényező, így a növényborítottság mértéke, a talaj víztartalma, a talaj humusztartalma, a talajszemcsék mérete, a lejtő szöge és hossza is befolyásolja. A jövőben a vízeróziós károk növekedésével kell számolnunk, mivel az elörejelzések alapján nő a csapadékok intenzitása (extrém esők megjelenése), a száraz időszakok megjelenése miatt csökkenhet a vegetáció borítottság, illetve a jobban felmelegedő talajfelszín kiszáradása is növeli a kockázatot. Európa területének 16\%-át veszélyezteti a vízerózió, különösen a szárazabb területeken, ahol a száraz időszakot jelentős cspadékok követik, számolhatunk a vízeróziós károk növekedésével (EU 2011). A vízerózió során elsősorban a talaj felső rétegeinek finom anyaga szállítódik el, ami azt jelenti, hogy csökken a talaj humusz- és tápanyagtartalma. Az erózió miatti sekélyebb termőréteg kevesebb vizet képes tárolni, így romlik az állományok vízellátottsága. A Keszthelyihegységben végzett vizsgálataink azt mutatták, hogy a feketefenyő állományok pusztulása elsősorban ott lépett fel, ahol a korábbi legeltetés miatt sekély termőrétegü köves-sziklás váztalajok, illetve rendzina talajok fordulnak elő (3. ábra). A vízerózió csökkentésére érdemes már most megfelelő intézkedéseket tenni. 


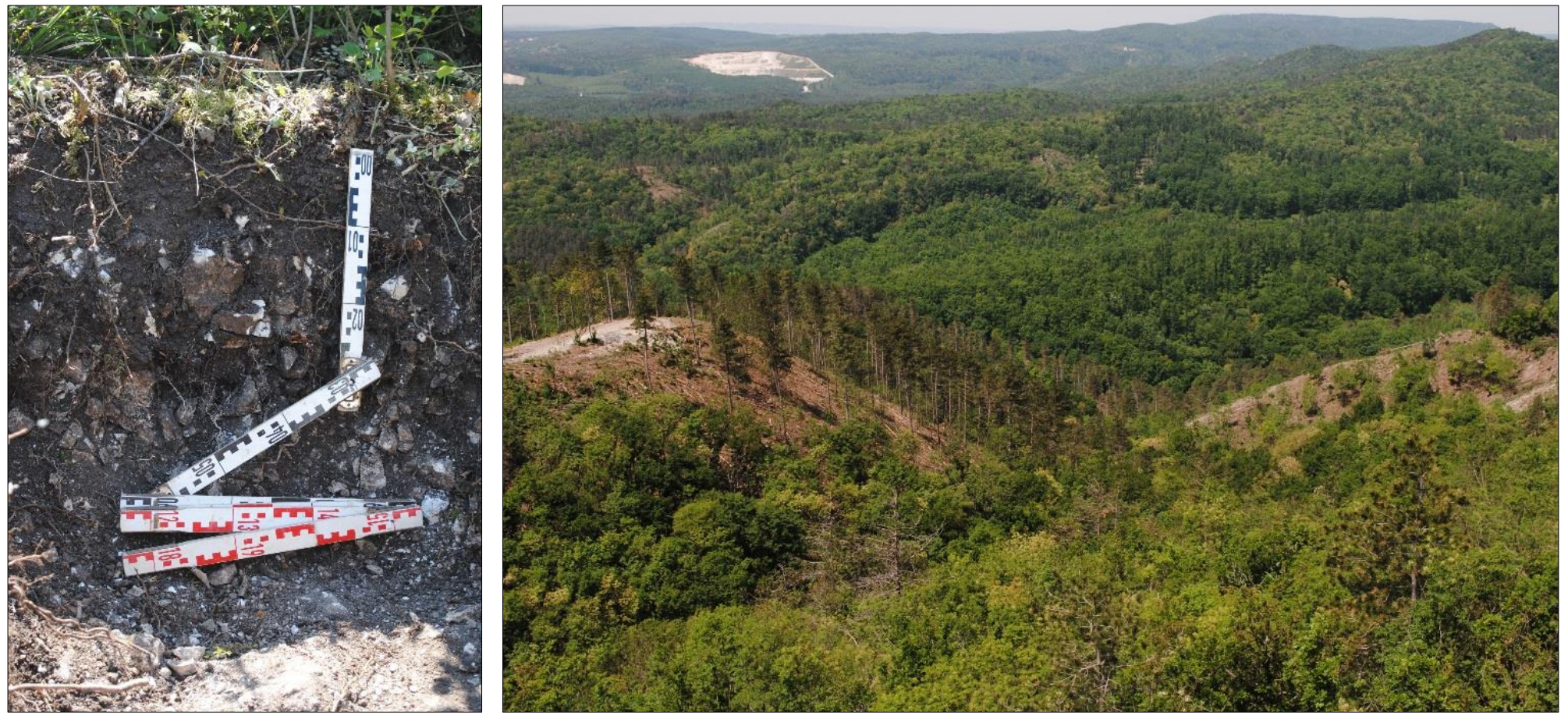

3. ábra: Köves-sziklás váztalaj és pusztuló fekete fenyő állomány a Keszthelyi-hegységben. Figure 3: Stony rocky skeletal soil and dying black pine stand in Keszthely Mountains. 


\section{Defláció}

A defláció (szélerózió) mértékét elsősorban a szél sebessége és örvényessége határozza meg, befolyásoló tényezői között a deflációs területek hosszát, a talaj szemcseösszetételét, szerkezetességét, és szervesanyag-tartalmát, a talaj felszín érdességét és nedvességtartalmát, valamint a növényborítottság mértékét szokták kiemelni (Stefanovits et al. 1999). A klímaváltozás hatására növekedni fog a jelentős sebességü szelek gyakorisága, valamint az alföldi területeken csökkeni fog a növényborítottság mértéke. Az egyes talajtípusokon eltérő az ún. kritikus sebesség, amely már megindítja az egyes talajszemcséket, míg homoktalajokon ez az érték 6,5 m/sec körüli, addig a kötött réti talajokon 9,6 m/sec is lehet (Lóki et al. 2005, Bartus et al. 2013). Ha a szél sebesége nő, akkor gyakrabban alakulhat ki olyan helyzet, amely már deflációval járhat. Mivel már jelenleg is a leggyakrabban az alföldi területeken lépnek fel deflációs károk, ezeken a területeken növekedhet a károkozás. Ez kettős hatással járhat, egyrészt csökken a termöréteg vastagsága, másrészt a szél által felkapott talajszemcsék jelentős kárt okozhatnak a „homokveréssel”, illetve a facsemeték betemetésével. A szélerózió hatással van az emberi egészségre is, a porterhelés közvetlen veszélyt, illetve légzőszervi megbetegedést okozhat. Mivel a széleróziós károk mértéke a szélsebesség - növénytakaró kapcsolattól függ, igen nehéz megbecsülni a károkokozás mértékének változását. Ugyanakkor érdemes kiemelni, hogy a múlt század elejéig az Alföld egyes részein alapvető probléma volt a defláció.

A korábbi vizsgálatokból tudjuk, hogy a megfelelö növénytakaró, különösen az erdősávok jelentősen csökkenthetik a defláció mértékét (Zentay 1989, Lóki 2003, Bartus et al. 2013). Hazánkban már a XIX. század első felében jelentős mezővédő erdősáv telepítés volt a szélcsökkentés (Keresztesi 1971), illetve a kedvező mikroklíma megteremtése érdekében (Kort 1988). Érdemes lenne megfontolni - különös tekintettel a klímaváltozás hatásainak csökkentésére - az erdősáv telepítések felújitását.

\section{A klímaváltozás hatása az erdőállományok anyagforgalmára}

A természetes erdők anyagforgalma közel egyensúlyi állapotban van. A növények által a légkörből származó széndioxid, a talajból felvett víz és mineralizált tápanyag mennyisége közel azonos a körforgalomba visszakerülő anyagok mennyiségével (Larcher 1994). Természetesen ezt az egyensúlyt a természeti „katasztrófák” pl. egy-egy idős fa kidőlése, az erdőtüzek, az abiotikus és biotikus károk megjelenése hosszabb - rövidebb ideig módosíthatja, illetve egyik irányba (pl. lebomlási folyamatok megerősődése) eltolhatja, de a természetes ökoszisztémák ezeket a „zavarokat” képesek kiegyenlíteni. Az egyensúlyi állapotot az antropogén hatások jelentősen megbontották, elsőként a termőföld nyerés érdekében végzett erdőirtások, majd a tervszerütlen fakitermelések jelentek meg, mely folyamatok nagyban veszélyeztették az erdoaállományok fennmaradását és használatát. $E$ felismerés vezetett, több, mint 300 éve a tartamosság fogalmának megalkotásához. Ugyanakkor a XIX. század közepe óta erdeinket olyan környezeti változások is érik, 
amelyeket már helyi szinten nem lehet kezelni. Ezek közül az első nagy változás hazánkban a folyószabályozás volt, ami jelentősen átalakította - különösen az alföldi - erdeink termőhelyi viszonyait. Mivel a folyószabályozás egyik fő célja éppen a szántóföldi müvelésre alkalmas termőföld nyerés volt, az akkor hegy- és dombvidéki erdőkben gazdag Magyarországon, az alföldi erdei termőhelyek visszaszorulása nem okozott gondot.

Az erdőállományok, illetve a talajok vízháztartásának megváltozása már önmagukban is jelentősen megváltoztatták az erdei ökoszisztémák anyagforgalmát, amihez csatlakozik a klímaváltozás okozta hatás. Sajnos hazai mérési eredményeink csak korlátozottan álnak a rendelkezésünkre, de nemzetközi eredmények alapján megbecsülhetjük a magyarországi erdőket érintő hatásokat. A klímaváltozás a hőmérséklet emelkedésével és a vegetációs időszak meghosszabodásával fokozhatja a fák növekedését és tápanyagfelvételét, de a gyakoribbá válló száraz időszakok pont ezzel ellentétes hatást válthatnak ki (Jolly et al. 2005, Rohner et al. 2016, Bircher et al. 2016). A hőmérséklet és a $\mathrm{CO}_{2}$-koncentráció növekedése együtt járt a talajban felvehető nitrogén mennyiségének növekedésével (Schlepp et al. 2002). Egy összefoglaló tanulmány szerint (Borken et. Matzner 2009) a mérsékelt égövi erdők szárazodása a talajban csekélyebb lebontást és nitrogén felszabadulást jelenthet. Ugyanakkor a légköri antropogén eredetü nitrogén depozició hatása sokkal erősebb, mint a klímaváltozás miatt bekövetkező lebontás csökkenés eredménye (Sutton et al. 2011). Az utóbbi fél évszázadban az atmoszférából származó nitrogén ülepedés jelentősen megnőtt, ami nagyban befolyásolja az erdőállományok tápanyagellátottságát, de a talaj (és a talajvíz) nitrogénkészletét is. A nitrogénszegény talajokon álló erdőállományokban ez a többlet fokozza a fák növekedését, abban az esetben, ha elegendő víz és tápanyag áll rendelkezésre (Pretzsch et al. 2018). Ha megbomlik a fák tápelemegyensúlya, azaz a többlet nitrogén miatt Ca-, Mg-, K-vagy P-hiány lép fel a levelekben, a növények érzékenyebbek lesznek a fagyra vagy a károsítókra, illetve növekszik a nitrát kimosódás a talajból. Utóbbi együtt jár más kationok kimosódásával, így a talaj savanyodásával. Hazai erdőállományaink esetén a fák tápelemfelvételét elsősorban a rendelkezésre álló víz határozza meg, mint limitáló faktor. Ennek megfelelően ritkán kell tápelem hiánnyal számolnunk az erdőállományokban. Mivel a jövőben a vegetációs időszak - a magasabb hömérséklet miatt - szárazabb lesz, így valószínüsithetö, hogy a jövőben is a víz lesz a meghatározó faktor a fák növekedése és tápelemfelvétele során.

\section{A klímaváltozás hatása a fafajválasztásra}

A fentiekben bemutattuk, hogy milyen hatással van a klímaváltozás a talajokra és az erdőállományok anyagforgalmára. Bár a hatások egy része hosszabb távon jelentkezik, a víz- és a szélerózió kárositása akár igen rövid idő alatt is megjelenhet. Ezek elsősorban a termőréteg csökkenése által fejtik ki kedvezőtlen hatásukat. A talajfejlődési folyamatokban bekövetkező változásoknál lényegesen gyorsabban jelenik meg az előrejelzések alapján az egyes klímatikus kategóriák térbeli eltolódása (Führer et al. 2017). Ez azt jelenti, hogy a jövőben olyan termőhelytípus változatok megjelenésével is kell számolnunk, amelyek eddig 
hazánkban nem fordultak elő. Ezek egy része a sztyep klímához kapcsolódik (ez a klíma kategória eddig nem volt hazánkban), más része a klíma területi „eltolódásával” jár együtt, azaz olyan talajtípusok is megjelenhetnek pl. az erdőssztyep klímában, amelyek kialakulásának feltételei más klímához és növényzethez kapcsolódnak. $E$ talajtípusok a megváltozott környezeti feltételek között idővel átalakulhatnak, de ez több évtizedes, vagy akár évszázados folyamatok eredménye lehet. Ennek megfelelően az új termőhelytípus változatokkal is kell számolnunk. Szükséges, hogy az új termöhelytípus változatokra is tudjuk fafaj javaslatokat adni. Ezt nem tehetjük meg a terepi tapasztalatok alapján, hiszen olyan termöhelytípus változatokkal kell számolnunk, amelyek jelenleg még nem fordulnak elő. Ezért a jelenlegi ismereteink alapján kell megbecsülnünk, hogy mely fafajok lesznek alkalmasak az új termőhelytípus változatokra. A becslést az adott klímában előforduló talajokkal való hasonlóság, illetve az egyes fafajok termőhelyi igényének figyelembevételével lehet megtenni. Ennek megfelelően került kiegészítésre a jelenleg alkalmazott célállomány táblázat.

\section{ÖSSZEFOGLALÓ ÉRTÉKELÉS}

A klímaváltozás közvetlenül, de más termőhelyi tényezők, mint a hidrológiai- és a talajviszonyok megváltoztatásán keresztül is jelentős hatással lesz az erdőállományainkra. Mivel az egyes termöhelyi tényezők szoros kölcsönhatásban vannak és közösen határozzák meg az erdőállományok előfordulását és növekedését mindenképpen szükséges, hogy a jövőben is együttesen értékeljük ki ezeket. A talajviszonyok értékelésénél nem mindig alapozhatunk a korábbi tapasztalatainkra, mivel egyes talajképző folyamatok megerősödhetnek, mások gyengülhetnek a klímaváltozás hatására. A klímaváltozás eredményeképpen új termöhelytípus változatok jöhetnek létre, amelyekre meg kell találnunk az alkalmazható fafajokat. Egyes esetekben kiindulhatunk a jelenleg meglévő hasonló termőhelytípus változatokra ajánlott fafajokból, de sok esetben olyan termőhelyekkel (pl. klimatikus viszonyokkal) találkozhatunk, amelyek korábban hazánkban nem fordultak elö, a hazai erdészeti kutatás és gyakorlat egyik nagy feladata, hogy fafaj javaslatukat tudjon adni ezekre a termöhelyekre is.

A klímaváltozás miatt egyes talajtulajdonságok szerepe megnövekszik. Ezek közé tartozik a talajok víztározó képessége, hiszen csak megfelelő vízellátottság mellett lesznek képesek erdeink a hosszabb szárazabb időszakot átvészelni. A talajok víztározó képességét elsősorban a talaj fizikai félesége és a termőréteg vastagsága határozza meg. Ezért is fontos, hogy az eróziós és deflációs károktól megvédjük talajainkat. Igen fontossá vállik a talajok szerves szén tartalma. Egyrészt ez javítja a talaj víztároló képességét, másrészt a talaj az egyik legfontosabb széntároló. Olyan gazdálkodást kell folytatnunk, amely megőrzi, ha lehet növeli a talajok szerves szén készletét.

Összefoglalva megállapíthatjuk, hogy bár nehéz elörebecsülni a klímaváltozás hatását talajaikra, a jövőben kiemelt feladat kell legyen a termőképesség megőrzése. 


\section{KÖSZÖNETNYILVÁNÍTÁS}

A kutatást az Agrárklíma.2 (VKSZ 12-1-2013-0034) projekt támogatta.

\section{FELHASZNÁLT IRODALOM}

AESZ (Állami Erdészeti Szolgálat) 2002: Magyarország Erdőállományai 2001. Állami Erdészeti Szolgálat, Budapest.

Babos I., Horváthné Proszt S., Járó Z., Király L., Szodfridt I. \& Tóth B. 1966: Erdészeti termőhelyfeltárás és térképezés. Akadémiai Kiadó, Budapest.

Bartholy J. \& Pongrácz R. 2017: A közelmúlt és a jövő országos éghajlati trendjei. (A klímaváltozáshoz alkalmazkodó erdőgazdálkodás kihívásai - II.) Erdészeti Lapok 152(5): 134-136.

Bartus M., Farsang A., Szatmári J. \& Barta K. 2013: Szélerózió becslése és modell alapú területhasználat optimalizáció a defláció veszélyeztetettség csökkentése érdekében, dél-alföldi mintaterületen. In: Dobos E., Bertóti R.D. \& Szabóné Kele G. (eds): Talajvédelem - Talajtan a Mezőgazdaság, a Vidékfejlesztés és a Környezetgazdálkodás Szolgálatában. (Különszám: Talajtani Vándorgyülés, Miskolc, 2012. augusztus 23-25.).Talajvédelmi Alapítvány, Magyar Talajtani Társaság és Miskolci Egyetem Földrajz Intézet, Miskolc, $57-66$.

Bidló A., Szűcs P., Horváth A., Király É., Németh E. \& Somogyi Z. 2014: Telepített kocsánytalan tölgy és akác fiatalosok hatása a talaj szénkészletére néhány dunántúli erdőtelepítés példáján. Erdészettudományi Közlemények 4(2): 121-133.

Bidló A., Novák T.J., Brúnó B. \& Horváth A. 2018: Peat transformation as a response on environmental changes under swampy alder forest. Geophysical Research Abstracts 20: EGU2018-17143.

Bircher N., Calleret M., Zingem A. \& Bugmann H. 2016: Potenziele Grundflächeveränderungen auf Bestandesebene im Klimawandel. In: Pluess A.R., Brang P. \& Augustin S. (eds): Wald im Klimawandel, Haupt Verlag, Bern, Stuttgart, Wien.

Blum W.E.H. 2007: Bodenkunde in Stichworten, Berlin-Stuttgart.

Borken W. \& Matzner E. 2009: Reappraisal of drying and wetting effects on $\mathrm{C}$ and $\mathrm{N}$ mineralization and fluxes in soils. Global Change Biology 15(4): 808-824. DOl: 10.1111/j.1365-2486.2008.01681.x

Csáki P., Szinetár M.M., Herceg A., Kalicz P. \& Gribovszki Z. 2018. Climate change impacts on the water balance - case studies in Hungarian watersheds. Időjárás 122(1): 81-99. DOI: 10.28974/idojaras.2018.1.6

EU (Europäische Kommission) 2011: Boden: Der verborgene Teil des Klimazyklus - Luxemburg. Amt für Veröffentlichungen der Europäischen Union. DOI: 10.2779/30430

Führer E., Czupy Gy., Kocsisné Antal J. \& Jagodics A. 2011: Gyökérvizsgálatok bükkös, gyertyános-kocsányos tölgyes és cseres faállományban. Agrokémia és Talajtan 60(1): 103-118.

Führer E., Csiha I., Szabados I., Pödör Z. \& Jagodics A. 2014: Egy cseres faállomány föld feletti és föld alatti szerves-anyagának meghatározása. Erdészettudományi Közlemények 4(2): 109-119.

Führer E., Gálos B., Rasztovits E., Jagodics A. \& Mátyás Cs. 2017: Erdészeti klímaosztályok területének várható változása. (A klímaváltozáshoz alkalmazkodó erdőgazdálkodás kihívásai - III.) Erdészeti Lapok 152(6): 174-177.

Jankó F. 2013: Elfeledett viták az alföldi erdősítés és vízrendezés éghajlati hatásairól. Földrajzi Közlemények 137(1): 51-63.

Jolly W.M., Dobbertin M., Zimmermann N.E. \& Reichstein M. 2005: Divergent vegetation growth responses to the 2003 heat wave in the Swiss Alps. Geophysical Research Letters 32: L18409. DOI: 10.1029/2005GL023252

Keresztesi B. 1971: Magyar Erdők. Akadémiai Kiadó, Budapest. 
Koch D. 2010: Langzeit-Entwicklung der Bodentemperaturen in verschiedenen Naturräumen Nodrhein-Westfalens. Diplomaerbeit, Geographisches Institut der Universität zu Köln.

Kort J. 1988: Benefits of Windbreaks to Field and Forage Crops. Agriculture, Ecosystems and Environment, 22-23: 165-190. DOI: 10.1016/0167-8809(88)90017-5

Larcher W. (eds): Ökophysiologie der Pflanzen. Ulmer Verlag, Stuttgart.

Lóki J., Rajkai K., Czyz E.A., Dexter A.R., Diaz-Pereira E., Dumitriu E., et al. 2005: SIDASS project: Part4. Wind erodibility of cultivated soils in north-east Hungary. Soil and Tillage Research 82(1): 39-46. DOI: 10.1016/j.still.2005.01.006

Magyar L. 1993: A Duna-Tisza közi hátság vízgazdálkodási problémái c. konferencia előadása: Hogyan érintik a hátság erdőgazdálkodását a vízgazdálkodási problémák? Erdészeti Lapok 128(7-8): 211-213.

Margóczi K., Rakonczai J., Barna Gy. \& Majláth I. 2009: Szikes növénytársulások összetételének és talajának hosszú távú változása a Szabadkígyósi pusztán. CRISICUM: A Körös-Maros Nemzeti Park Igazgatóság időszakos kiadványa 5: 71-83.

Pretzsch H., Biber P., Schütze G., Kemmerer J. \& Uhl E. 2018: Wood density reduced while wood volume growth accelerated in Central European forests since 1870. Forest Ecology and Management 429: 589 616. DOI: $10.1016 /$ j.foreco.2018.07.045

Rohner B., Braun S., Weber P. \& Thürig E. 2016. Wachstum von Einzelbäumen: das Klima als Baustein im komplexen Wirkungsgefüge. In: Pluess A.R., Augustin S. \& Brang P. (eds): Wald im Klimawandel, Haupt Verlag, Bern, Stuttgart, Wien. 137-155.

Schachtschabel P., Blume H.P., Hartge K.H. \& Schwertmann U. 1982: Lehrbuch der Bodenkunde. Ferdinad Erike Verlag, Stuttgart.

Somogyi Z., Bidló A., Csiha I. \& Illés G. 2013: Country-level carbon balance of forest soils: a country-specific model based on case studies in Hungary. European Jounal of Forest Research 132(5-6): 825-840. DOI: 10.1007/s10342-013-0718-x

Stefanovits P., Fülep Gy. \& Füleky Gy. 1999: Talajtan. Mezőgazda Kiadó, Budapest.

Sutton M.A., Howard C.M., Erisman J.W., Billen G., Bleeker A., Grennfelt P., et al. 2011: The European Nitrogen Assessment Sources, Effects and Policy Perspectives. Cambridge University Press.

Szodfridt I. 1993: Erdészeti termőhelyismeret-tan. Mezőgazda Kiadó, Budapest.

Szodfridt I. 1994. Az erdők és a talajvíz kapcsolata a Duna-Tisza közi homokhátságon. A Nagyalföld Alapítvány kötetei 3. Békéscsaba, 59-67.

Tóth T., Kuti L., Kabos S. \& Pásztor L. 2001: Az alföldi szikes talajok elterjedését meghatározó agrogeológiai tényezok térinformatikai elemzése 1:500 000 méretarányban. In: Dormány G., Kovács F., Péti M. \& Rakonczai J. (eds): A földrajz eredményei az új évezred küszöbén: A Magyar Földrajzi Konferencia tudományos közleményei. Szeged, 2001.10.25-27. Szegedi Tudományegyetem TTK Természeti Földrajzi Tanszék, Szeged.

Tóth T. \& Szendrei G. 2006: A hazai szikes talajok és a szikesedés, valamint a sófelhalmozódási folyamatok rövid jellemzése. In: Szendrei G. \& Tóth T. (eds): A magyarországi szikes talajok felszíni sóásványai. (Topographia Mineralogica Hungariae, IX.) Herman Ottó Múzeum, Miskolc, 7-20.

Zentay T. (eds) 1989: A szélerózió elleni védekezés lehetőségeinek módszereinek feltárása Csongrád-megye homokterületein. Magyar Tudományos Akadémia Szegedi Akadémiai Bizottságának Kiadványai, Szeged.

Érkezett: 2018. május 7.

Közlésre elfogadva: 2018. június 1. 